impressive example of the problem of climatic conditions raised by arctic fossil plants. Prof. Harris has been able to distinguish many species of Ginkgo (or Ginkgoites) by an examination of the epidermal structure of the leaves. He has also described species of Czekanowskia, Baiera, Phœnicopsis, and Torellia, a ginkgoalean genus previously recorded from Grinnell Land, still farther north ; together with a new generic type which he has named Hartzia.

It is noteworthy that several species of these different members of the Ginkgoales recorded from Mesozoic floras north of the Arctic Circle are either identical with or closely allied to species previously described from Europe and the Far East.

The genera already mentioned do not exhaust the list of ginkgoalean trees discovered in Mesozoic floras of the world : we are concerned only with arctic forms.

The two photographs, Fig. $2(a)$ and $(b)$, for which I am indebted to Dr. Florin, illustrate the striking similarity in the stomatal apparatus of a fossil leaf and a leaf of the existing species. In both preparations of the epidermal film there is the same general arrangement of subsidiary cells encircling the stomatal pore. The thick black bands mark the position of strongly cuticularized cell walls. Fig. $2(a)$ shows the epidermal structure of a leaf of Ginkgo adiantoides from Upper Tertiary beds (Pliocene) near Frankfort-onMain : Fig. $2(b)$ is from a leaf of Ginkgo biloba. The Frankfort leaves and others recorded from Pliocene beds in the Rhone Valley prove the existence of Ginkgo in Europe so late as the latter part of the Tertiary period shortly before the beginning of the Great Ice Age. We know that Ginkgo was a member of an early Tertiary (Eocene) flora on the basaltic plateau of which the Island of Mull is a detached fragment. The Ginkgo leaves from Mull in the Starkie Gardner collection in the British Museum
(Natural History) are exceptionally beautiful examples of fossil foliage.

We cannot say with certainty when the Ginkgo family first appeared in the vegetation of the world; there is, however, some evidence of its existence as early as the Permian period. We know that it had reached an advanced stage of development before the end of the Triassic period in both the northern and the southern hemisphere. The family continued to occupy a prominent position almost throughout the world in the Jurassic and in the early part of the Cretaceous

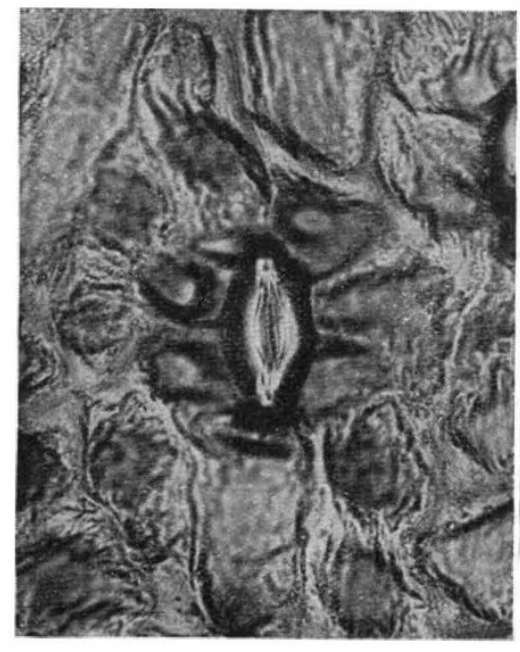

(a)

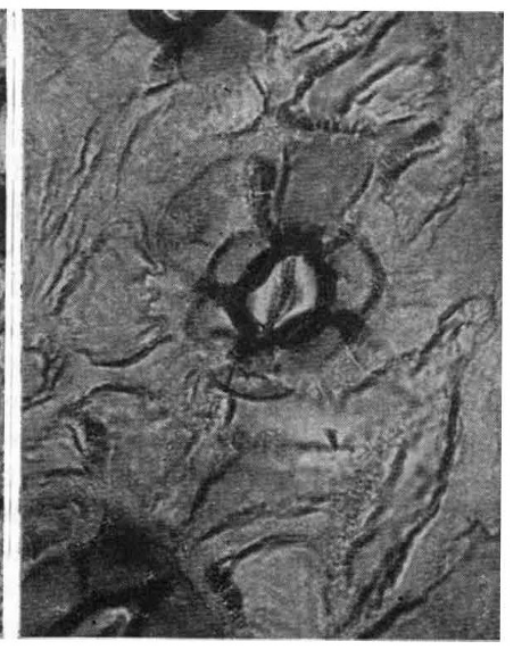

(b)

Fig. 2.

Stoma AND ADJACENT Cells on the lower SURfaCe of a leaf of (a) Ginkgo adiantoides (UNGER) HEER; (b) Ginkgo biloba L. $\times 400$. AFTER R. FLORIN.

period. The genus Ginkgo persisted as a widely distributed tree well into the Tertiary era.

This brief account may serve to give point to Darwin's description of the maidenhair tree as "a living fossil", and especially to emphasize the fact that this sacred tree is the solitary living representative of a large company of genera which played a conspicuous part in the vegetation of the world through successive geological periods.

\footnotetext{
${ }^{2}$ Contrib. Biol. Lab. Sci. Soc. China, 8, No. 3, 3 (1933).

${ }^{2}$ Palaeontographica, 81 and 82 , Abt. B. (1936).
}

\title{
The Nottingham Meeting of the British Association
}

$\mathrm{T}^{\mathrm{H}}$ HE preliminary programme of the British Association meeting at Nottingham has been issued, and is obtainable from the offices of the Association at Burlington House, London, and at Commerce Chambers, Elite Building, Nottingham.
The meeting will be held on September 1-8, and Sir Edward Poulton will be the president.

This will be the third time the Association has met in Nottingham. In 1866, the versatile Queen's Counsel and fellow of the Royal Society, William 
R. Grove, presided over a meeting there, and in 1893 the president was Burdon Sanderson. On the first occasion, it was necessary to use 'the theatre' for the major meetings; on the second, the Albert Hall was available, and here again, next September, the presidential address will be given. In it, Sir Edward Poulton will review the history of evolutionary thought, as recorded in the meetings of the Association, a subject of very wide general interest, peculiarly appropriate to the Association which maintains Darwin's home as a national memorial, and fortunately chosen by one whose personal relations with the Association have been so intimate, over so long a period, as the president's.

For the rest, practically the whole of the meeting will find a new and very attractive venue in the University College. The old building in the centre of the city was in use in 1893, but now a fine new college occupies a beautiful and even inspiring site three miles from the centre, and here, or in the immediate vicinity, all the sections will meet, the reception room will be established, and many of the visiting members will be housed in the excellent hostels. Lest any who live or will be staying in the heart of the city should fear that the distance of the College will be a drawback, it should be stated that ample means of conveyance will be arranged, and that the city authorities are making generous provision for the free transport of visiting members. The convenience of concentrating so much of the business at a single centre is manifest.

The first evening discourse will be given by $\mathrm{Dr}$. R. E. Slade on the suggestive subject of grass and the national food supply, and the secondarranged too late to be included in the preliminary programme-by Prof. J. Gray, who will deal with the movements of fish. The provision of lectures to the public, which the Association always undertakes if asked to do so, has found a wide welcome, for such lectures have been asked for, and will be given, in Nottingham itself (by Prof. H. Hartridge, on illusions of colour) and in Derby, Lincoln, Long Eaton, Mansfield, and Newark.

The sections already announce a number of principal items in their programmes, of both general and special interest. The full list is too long to detail, but reference may be made to the unusual feature of six sections (Geography, Geology, Zoology, Botany, Agriculture, and Economics) contributing to an evening discussion on planning the land of Britain. An extensive series of excursions and visits is planned. Nottingham itself is a centre of unusually varied scientific interest, in respect of its manifold industrial and historical features, and it commands a district, from Derbyshire on one hand to Lincolnshire on the other, possessing a scenic and economic variety remarkable even in England. A civic reception will be given in Nottingham Castle, and a garden party at the University College.

Occasion is taken to announce in this preliminary progranme certain matters not relating to the annual meeting, among them the new activity of the Association in arranging the Alexander Pedler and Norman Lockyer lectures, taken over from the British Science Guild since that institution was incorporated into the Association. The Pedler lecture will be given by Prof. Allan Ferguson in Leicester, in co-operation with the University College in that city, on Monday, May 3, at 8 p.m. The Norman Lockyer lecture will be given in the Goldsmiths' Hall, Foster Lane, London, by kind permission of the Goldsmiths' Company, on Wednesday, November 24, by Dr. R. E. Mortimer Wheeler.

\section{Obituary Notices}

\section{Prof. D. A. Low}

$\mathrm{T}^{\circ}$ O Prof. David Allan Low, emeritus professor of engineering, East London College, University of London, who died on March 24, a host of distinguished engineers, andiarchitects and chemists scattered throughout the Empire are a living memorial. Few men in fact have had greater influence on the technical education of Great Britain by his lectures and by his text-books. Probably the most successful writer of engineering text-books who ever lived, his influence has extended to every university and technical college throughout the English-speaking world.

Prof. Low was extraordinarily patient, rarely angered, amazingly thorough, great beyond words in his efforts to help his friends, a man to whom a man could anchor his affections and loyalty, a man whom it was a privilege to serve, a great engineer. $\mathrm{H}_{\theta}$ never said a word against anyone. Perhaps his greatest characteristics were his extraordinary thoroughness and imperturbability. Was not the great success of his students in after-life are flection of these characteristics?

On his seventieth birthday, a banquet and presentation was held in his honour by a large number of old students, and on February 9 last-his eightieth birthday-some of his intimates dined together at the "Cheshire Cheese". It was one of those simple, informal, unforgettable occasions, with everyone in perfect harmony inspired by an abiding affection. 